Universidad Autónoma de Chile. Santiago, Chile.

aPsicóloga. PhD en Psicología.

Conflict of interest: The authors have no potential conflicts of interest to report.

This study was funded by the Universidad Autónoma de Chile through its 2015 Research Fund Program.

Recibido el 8 de septiembre de 2017, aceptado el 20 de febrero de 2018.

Correspondencia a: Erica Villoria

Ricardo Morales 3369, San Miguel.

Santiago, Chile.

erica.villoria@uautonoma.cl

\section{Assessment of the Hospital Anxiety and Depression Scale for cancer patients}

\author{
ERICA VILLORIA ${ }^{a}$, LAURA LARA ${ }^{a}$
}

\begin{abstract}
Background: Depression and anxiety are common in patients with cancer. Aim: To adapt and validate the Hospital Anxiety and Depression Scale (HADS) for adult Chilean cancer patients, and to provide information about their prevalence of anxiety and depression. Material and Methods: Two hundred fifteen patients with cancer answered an adapted version of HADS for Chilean population. The language adjustment of the scale was carried out with the opinions of 10 expert linguists and with a pilot study on 17 cancer patients. The Depression and Anxiety subscales of the DASS-21 were also applied to verify the convergent validity of HADS: Results: The confirmatory factor analysis indicated that the data fits the model of two correlated factors (anxiety and depression), $\chi^{2}=98.608$; $d f=76 ; p<0.05 ; \chi^{2} / d f=1.23, R M S E A=0.037 ; C F I=0.99 ; T L I=.98$. Reliability analysis showed an adequate internal consistency of both subscales (.76 for anxiety and .84 for depression) and the general scale (.87). Correlations between HADS and DASS-21 scores were significant for both anxiety $(r=.514, p<0.001)$ and depression $(r=0.600, p<0.001)$. Prevalence rates were approximately $30 \%$ for depression (actual $=12 \%$, possible $=22.8 \%$ ) and approximately $20 \%$ for anxiety (actual $=7 \%$, possible $=8.4 \%$ ). Conclusions: We conclude that HADS is a reliable and valid instrument for screening clinically relevant anxiety and depression symptoms in Chilean cancer patients.
\end{abstract}

(Rev Med Chile 2018; 146: 300-307)

Key words: Anxiety; Depression; Cancer; Psychometrics.

\section{Adaptación y validación de la Escala de Ansiedad y Depresión Hospitalaria en pacientes chilenos con cáncer}

Objetivo: Adaptar y validar la Escala Hospitalaria de Ansiedad y Depresión (HAD) a población adulta oncológica chilena y aportar información sobre la prevalencia de ansiedad y depresión en la muestra. Método: Participantes: 215 pacientes oncológicos. Instrumentos: Protocolo de datos sociodemográficos y clínicos; HAD y el DASS-21, utilizada como Gold Standar para comprobar la validez de convergencia de la escala. Procedimiento: adaptación lingüística de la escala mediante juicio de expertos lingüistas $(n=10)$ y pilotaje con 17 pacientes oncológicos. Resultados: El análisis factorial confirmatorio indica que la escala se ajusta al modelo de dos factores correlacionados (ansiedad $y$ depresión) $\left(\chi^{2}=98,608 ; g l=76 ; p<0,05 ; \chi^{2} / g l=1.23 ; R M S E A=0,037\right.$; $C F I=0,99 ; T L I=0,98)$. Los análisis de confiabilidad ponen de manifiesto una adecuada consistencia interna tanto de las subescalas que la componen (0,76 
para ansiedad y 0,84 para depresión) como de la escala general (0,87). Las correlaciones entre las puntuaciones del HAD y el DASS-21 fueron positivas $y$ significativas tanto para ansiedad $(r=0,514, p<0,001)$ como para depresión $(r=0,600, p<0,001)$. Se señalan cifras de prevalencia en torno al $30 \%$ para depresión (caso $=12 \%$; posible $=22,8 \%$ ) y al $20 \%$ para ansiedad (caso $=7 \%$; posible $=8,4 \%)$. Conclusiones: El HADS es un instrumento válido y confiable para el screnning de sintomas de ansiedad y depresión de relevancia clínica en pacientes oncológicos chilenos.

Palabras clave: Cáncer, ansiedad, depresión, validez, fiabilidad.

$\mathrm{D}$ espite huge advances in the study of cancer, its incidence and mortality are still extremely important. According to data from the International Agency for Research on Cancer, in 2012, 14.1 million new cases and an 8.2 million mortality rate were reported worldwide ${ }^{1}$. In Chile, the Ministry of Health ${ }^{2}$ in 2009 reported that cancer is responsible for $23 \%$ of total deaths, constituting the second leading cause of death after cardiovascular diseases. Additionally, every year, over 37,000 people are hospitalized for this disease, and over 30,000 new cases are estimated.

Based on its epidemiological importance, over the last few decades, literature has shown that cancer affects all aspects of a patient's life and social network. Cancer entails a combination of symptoms and limitations associated with the disease and/or treatment that, from the moment of diagnosis, can imply high emotional impact with powerful repercussions on patients' quality of life $\mathrm{e}^{3-8}$. In this way, emotional disturbances, particularly anxiety and depression, are present in about $20-40 \%$ of cancer patients ${ }^{9-13}$. Studies also stress the importance of the evaluation of emotional disturbance, and that of possible protocols for psychological intervention more adequate to these patients ${ }^{14-19}$. Although few groups in Chile have delved into this subject, the available results are coincident with international ones, and point to the necessity for adequate instruments for the evaluation of emotional disturbances in cancer patients ${ }^{20}$.

Studies with cancer patients also indicate that these emotional disturbances are correlated with worse physical conditions and more severe symptoms (pain, fatigue, sleep difficulties, etc.), and with patient's therapeutic response $\mathrm{e}^{21-23}$. However, this relation is complex, and it is necessary to further investigate its direction ${ }^{14}$.
Available data, occasionally contradictory, have generated a large research field, focused on determining the psychopathological degree of patients' emotional responses, as well as the adequacy and appropriateness of evaluation instruments and diagnostic criteria ${ }^{24,25}$.

All the above, highlights the relevance of emotional state throughout different phases of the disease and the need for its evaluation using instruments that ensure the reliability and validity of the data acquired ${ }^{26}$. The study of depression and anxiety in cancer patients requires the development of instruments specific to such a population, since anxiety and depression can be confused with several symptoms typical of the disease (for example, loss of appetite, fatigue, tiredness, and insomnia). The Hospital Anxiety and Depression Scale (HADS) ${ }^{27}$ was created to this end, to evaluate the emotional state of non-psychiatric subjects with physical disease cared for in outpatient hospital services ${ }^{28}$. HADS is a screening tool that can help to quickly and effectively identify patients that show symptoms of depression and/or anxiety. At present, its use in the health-care setting has been increasing, since it evaluates cognitive, emotional, and behavioral symptoms, excluding physical symptoms. Thus, it avoids possible false positives, at the same time as excluding symptoms associated with severe mental disorders. Once patients are identified as having possible symptoms of depression and/or anxiety, they can be selected for a diagnostic confirmation.

Previous studies have shown the adequacy of HADS in evaluating emotional condition in the physically sick, and, specifically in cancer patients ${ }^{29-32}$, showing its good psychometric characteristics and confirming its bifactorial structure, as proposed by Zigmond and Snaith ${ }^{27,33-37}$. However, despite being shown to be a reliable and accepta- 
ble instrument for these patients, some studies question the autonomy of the two subscales that comprise it (see the revisions by Norton, Cosco, Doyle, Done, \& Sacker $^{38}$, and Terol et al. ${ }^{37}$ ), as well as the adequacy of the cut-offs for considering someone as a clinical case ${ }^{31}$. However, despite these weaknesses, HADS use as a screening instruments is of great interest for its ability to differentiate responses to anxiety and depression ${ }^{39,40}$. Being a simple, easy-to-apply instrument, it is particularly suitable for the physical-disease setting, as this makes it easier for subjects to complete the questionnaire. In this context, it can be used as a screening instrument for anxiety and depression and to assess the psychological impact during the process of the disease and its treatment, as well as to assess the results after psychological interventions $\mathrm{s}^{36,41,42}$. On the other hand, the large quantity of psychooncology research being conducted in different countries, emphasizes its use also as an outstanding instrument to measure the psychological dimension of quality of life, given its association with functional status, among other parameters $^{31}$.

In this context, and given the need for instruments adapted and validated for adult Chilean cancer patients, the present study has two objectives. Firstly, the Chilean version of the HADS psychometric characteristics will be analyzed, verifying the adequacy of its factorial structure, internal consistency, and convergence validity. Secondly, descriptive results on anxiety and depression levels of cancer patients will be reported, providing information about its prevalence, and giving guidelines for adequate management of hospital resources, according to the needs of both the patients and the hospital, with consequences for patients' quality of life and for health politics.

\section{Material and Method}

\section{Participants}

In this study, 215 cancer patients participated, who were adults and undergoing treatment at the Instituto Oncológico Fundación Arturo López of Santiago, Chile, a comprehensive center for the diagnosis, treatment, research, and education in cancer, which treats patients from all over Chile. Exclusion criteria include physical and mental conditions that impede participants' ability to respond to the measures. All the participants were adults, between 23 and 89 years of age $(\mathrm{M}=58.71$, DS $=11.65)$, and $72.1 \%$ of them were women. Most were in a relationship (67.4\%), while the rest were single $(14.9 \%)$, divorced $(8.8 \%)$, or widowers $(8.8 \%)$. With regards to their education level, most had university degrees (41.4\%) and high-school diplomas $(41.4 \%)$, followed by primary education $(10.7 \%)$, and, in a single case $(0.5 \%)$, no education was completed. Most of the participants were not working at the time data were collected, due to retirement (31.1\%), sick leave (29.8\%), or unemployment (3.3\%); of those working, only $19.1 \%$ were employed, while the remaining $15.8 \%$ were homemakers. Finally, clinical characteristics are summarized in Table 1.

\section{Instruments}

Hospital Anxiety and Depression Scale (HADS). To adapt the scale for Chilean cancer patients, we used the Spanish version ${ }^{31}$ of the original scale ${ }^{27}$. A 14-item scale divided into two subscales, anxiety and depression, each one comprising 7 items (depression for even items and anxiety for odd ones). The items are assessed through a Likert scale, ranging from 0 to 3 , with the higher scores indicating more severe anxiety and depression.

Table 1. Clinical characteristics of the sample

\begin{tabular}{|lc|}
\hline Characteristics & \% \\
Type of cancer & \\
Breast & 39 \\
Colon & 10.5 \\
Prostate & 5.7 \\
Uterine & 5.2 \\
Others* & 60.4 \\
Medical treatment & \\
Hospitalized & 3.3 \\
Chemotherapy & 55.8 \\
Radiotherapy & 39.5 \\
- & 1.4 \\
Disease stage & \\
O & 2.8 \\
I & 17.2 \\
III & 31.6 \\
IV & 27.4 \\
- & 14.9 \\
\hline
\end{tabular}

Note: ${ }^{*} 23$ different types of cancer with $\%<5.0$. 
Scores are assessed according to the criteria suggested by Zigmond and Snaith ${ }^{27}$ : score of 0 to 7 , no symptoms; score of 8 to 10, borderline case; and score of 11 to 21 , clear symptoms of depression and/or anxiety.

Depression Anxiety Stress Scales (DASS-21). The Depression and Anxiety subscales of the DASS-21 scale were used to analyze the convergent validity of the same HADS subscales, using the Chilean validation $^{44}$ of the original scale developed by Lovibond and Lovibond ${ }^{45}$. It is a 21 -item scale that measures stress ( 7 items), anxiety ( 7 items), and depression (7 items), with responses from 0 (does not apply to me at all) to 3 (applies to me very much, or most of the time).

\section{Procedure}

Ethical approval was obtained from the Ethical Committees of both the sponsoring University and the Oncology Institute where the study was conducted. All participants were informed about the aims of the study and gave their written consent to participate. Participants were chosen randomly from among adult patients receiving treatment at one oncologic institute, until reaching the required sample size to perform the statistical analysis. The exact sample required to perform Confirmatory Factor Analyses cannot be determinate prior to sample collection, because of its demand for multiples factors that we cannot know beforehand ${ }^{46}$. We determined a minimum of 200 participants based on: (a) a minimum sample size of 100 or $200^{47}$ and (b) 5 or 10 observations per estimated parameter $^{48}$. The questionnaires were administered individually to each patient on hospital grounds by a member of the research team.

\section{Analysis of data}

Confirmatory Factor Analyses (CFAs) were performed, using the Mplus version 7.3 software, on a polychoric correlation matrix with the estimate method of Robust Unweighted Least Squares (ULSMV). Adjustment indices included Root Mean Square Error of Approximation (RMSEA $<.080)$, Comparative Fix Index (CFI > .90), and Tucker Lewis Index (TLI > .90, threshold values suggested by Arbuckle $\left.{ }^{49}\right)$. Descriptive statistics, analysis of internal consistency (Cronbach's alpha of $>.70)$, and correlations for the scales $(<.10$ low; between $>.10$ and $<.50$ average; $>.50$ high) were performed with SPSS, version 21 software.

\section{Results}

\section{Language adaptation of the HADS}

Firstly, the Spanish version of $\mathrm{HADS}^{31}$ was revised by 10 Chilean experts in psychology, who independently verified the adaptation of the items in Chile and suggested improvements to the wording. These suggestions were small variations in some words and expressions. The adapted items were later verified with the participation of 17 cancer patients of the same hospital, who were asked, individually and in writing, in the presence of one of the researchers, to say if they understood the items, and, if not, to show where the difficulty lay and which improvement options they suggested for aiding their understanding. All patients understood the items correctly and found no difficulties in doing so. In the Attachment, the final Chilean version of the questionnaire is presented.

\section{Structural validity}

Firstly, we developed a CFA to verify the adjustment of the factorial solution found in previous studies, i.e., the existence of two related factors (anxiety and depression). The estimate, through the robust unweighted least squares method (ULSMV), showed adequate fit indices to the original model of two correlated factors $\left(\chi^{2}=98.608 ; d f=76 ; \mathrm{p}<.05 ; \chi^{2} / d f=1.23 ; \mathrm{RM}-\right.$ $\mathrm{SEA}=.037$; CFI $=.99 ; \mathrm{TLI}=.98)$. Figure 1 shows a graph of the model.

\section{Internal consistency}

The reliability analysis (Cronbach's alpha) showed adequate internal consistency of the HADS scale; with alpha values of .87 for the total of 14 items, .76 for anxiety, and .84 for depression.

\section{Concurrent validity}

The results of correlations between scores for the anxiety and depression factors, measured for HADS and for DASS-21, are positive and significant both for anxiety $(\mathrm{r}=.514, \mathrm{p}<.001)$ and for depression $(r=.600, p<.001)$.

\section{Descriptive analysis}

The mean score for the HADS depression subscale was $6.18(\mathrm{SD}=3.63$, range: $\min =0, \max =$ $18)$. In relation to the anxiety subscale, the mean score was $3.88(\mathrm{SD}=3.66$, range: $\min =0, \max =$ 17). About prevalence of anxiety and depression in 


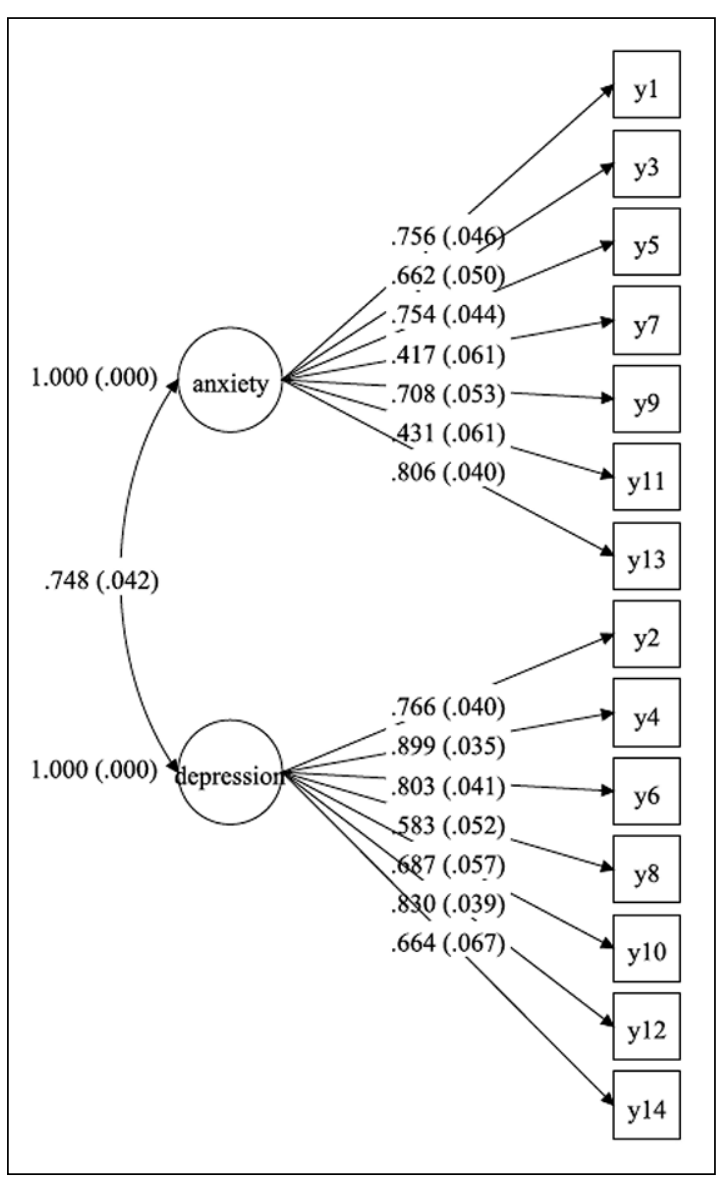

Figure 1. CFA.

the sample (Table 2), according to the scale cutoff values $^{27}, 12.2 \%$ of the sample had depression, with an additional $22.8 \%$ of possible cases, while $7 \%$ of the sample had anxiety, with an additional $8.4 \%$ of possible cases.

\section{Discussion}

In relation to the psychometric characteristics of the HADS scale, it can be concluded that it is adequate to be used with Chilean cancer patients. Firstly, the results of the confirmatory factor analysis show that the HADS has an adequate fit with the original two correlated factors model for the Chilean cancer population. Thus, we confirm that the structure of the scale is similar to that reported in other countries with cancer patients ${ }^{30,31}$,
Table 2. Prevalence of anxiety and depression

\begin{tabular}{|lcccc|}
\hline & \multicolumn{2}{c}{ Depression } & \multicolumn{2}{c|}{ Anxiety } \\
Cutoff value & $\mathbf{n}$ & $\mathbf{\%}$ & $\mathbf{n}$ & $\mathbf{\%}$ \\
\hline Actual $(11-21)$ & 26 & 12.1 & 15 & 7 \\
\hline Possible $(8-10)$ & 49 & 22.8 & 18 & 8.4 \\
None $(0-7)$ & 140 & 65.1 & 182 & 84.7 \\
\hline
\end{tabular}

as well as in other populations of the physically sick $^{33,35,37,50}$.

Secondly, the results of the reliability analysis of the HADS scale also shows adequate internal consistency of both subscales that it comprises and of the scale in general, according with previous studies $^{31,33,36}$. Finally, the high correlations with the anxiety and depression scales measured for the DASS-21 scale offer further information on the construct validity of the scale. Similar results were registered in other studies, where positive and significant correlations are reported between the HADS scale and other instruments for measuring anxiety and depression as external criteria ${ }^{31,43}$.

Regarding the prevalence of anxiety and depression in the participants, results show the presence of anxiety and, particularly, depression symptoms, without clinical relevance. These results are in accordance with studies on cancer patients that reported lower prevalence rates of emotional disturbances in this population $^{15,17,19,51-53}$. It must be noted that several studies have highlighted that critical moments of the disease (such us diagnosis, recurrence, palliative care) could imply a higher impact on emotional state, as well as a worse prognosis or physical conditions that derive from the disease and/or cancer treatments ${ }^{52,54-56}$. As most of our participants were in stages I and II, which, a priori, would entail better prognosis and evolution, it could explain the low presence of pathological emotional distress. However, the variables measured in this study do not allow us to draw conclusions, as other aspects should be considered, such as critical moments, symptoms, functionality, social support, etc. This suggests a need to analyze these aspects in more detail in future research. However, as already stated and highlighted by other authors, there are discrepancies regarding the cutoff values for determining the actual existence of anxiety and/or depression. Different studies chose lower values, 
with cutoffs of about 8 for anxiety and about 4 for depression ${ }^{29,31,34}$. In this sense, our results could indicate higher rates of emotional disturbances in cancer patients. In the review by Terol et al. ${ }^{37}$, this problem is presented, offering the possible solution of choosing cut off values according to the study sample. Additionally, they suggest further investigation is needed in samples with different clinical and socio-demographic characteristics, with different health conditions that could allow drawing firmer conclusions regarding the use of HADS as a screening instrument, as well as for psychological interventions, in these samples ${ }^{57}$.

In summary, our results, based on factor analysis, internal consistency, and criterion validity, suggest that HADS is adequate for the evaluation of emotional state in Chilean cancer patients. This gives us an evaluation instrument to identify anxiety and depression symptoms, which could have clinical relevance, mediate the process of adjustment to disease, and improve treatment and compliance with therapeutic interventions and medical prescriptions; in short, it is an instrument that could improve patient's quality of life. Having an instrument adequate for screening may improve the management of health resources through efficient public health policies, all supporting the needs of the patients and of hospitals. This would help to isolate the most appropriate psychological interventions to ensure better coping with and adjustment to the disease.

Despite the relevance of these findings, this study has some limitations. It is necessary to continue investigating the scale's sensitivity and specificity, as well as its cutoff values, to achieve more complete and conclusive results. Thus, it will be possible to better define patients with clinically-relevant symptoms and those who can benefit from a psychological intervention adapted to their characteristics. Moreover, it is necessary to study other variables relevant in cancer patients according to published literature. Therefore, we stress the importance of continuing investigation in this direction, with the possibility for using an adapted and validated instrument adequate to this population.

Aknowledgements: This study was funded by the Universidad Autónoma de Chile through its 2015 Research Fund Program (Ref: Dip-46) and was conducted with the help of several professio- nals from Instituto Oncológico Fundación Arturo López Pérez (Chile).

\section{References}

1. Agencia Internacional de Investigación del Cáncer. Proyecto Globocán; 2012 [cited 2017]. Available from: http://globocan.iarc.fr/Default.aspx

2. Ministerio de Salud. Gobierno de Chile. (http://epi. minsal.cl/registros-poblacionales-cancer/) [cited 2017].

3. Berrocal C, Rivas T, Venditti F, Bernini O. On the contribution of psychological flexibility to predict adjustment to breast cancer. Psicothema 2016; 28 (3): 266-71.

4. Fallowfield L. Treatment decision-making in breast cancer: the patient-doctor relationship. Breast Cancer Res Treat 2008; 112: 5-13.

5. Irarrázaval $\mathrm{ME}$, Kleinman $\mathrm{P}$, Silva $\mathrm{F}$, Fernández L, Torres C, Fritis M, et al. Calidad de vida en pacientes chilenas sobrevivientes de cáncer de mama. Rev Med Chile 2016; 144: 1567-76.

6. Montarezi A. Health-related quality of life in breast cancer patients: a bibliographic of the literature from 1974 to 2007. J Exp Clin Cancer Re 2008; 27 (1): 27-58.

7. Stark D, Kiely M, Smith A, Velikova G, House A, Selby P. Anxiety disorders in cancer patients: their nature associations and relation to quality of life. J Clin Oncol 2002; 20 (14): 3137-48.

8. Yokoyama T, Kurokawa Y, Kani R, Takatori E, Nokiguchi S, Suzuki Y, et al. Assessment of health-related quality of life in cancer outpatients treated with chemotherapy. Cancer and Chemotherapy 2012; 39 (3): 409-14.

9. Bardwell WA, Fiorentino L. Risk factors for depression in breast cancer survivors: An update. International Journal of Clinical and Health Psychology 2012; 12 (2): 311-31.

10. Brintzenhofe-Szoc KM, Levin TT, Li Y, Kissane DW, Zabora JR. Mixed/depression symptoms in a large cancer cohort: prevalence by cancer type. Psychosomatics 2009; 50: 383-91.

11. Ho RTH, Kwan TTC, Cheung IKM, Chan CKP, Lo PHY, Yip PSF, et al. Association of Fatigue with Perceived Stress in Chinese Women with Early Stage Breast Cancer Awaiting Adjuvant Radiotherapy. Stress and Health 2015; 31: 214-21.

12. Mitchell AJ, Chan M, Bhatti H, Halton M, Grassi L, Johansen C, et al. Prevalence of depression, anxiety, and adjustment disorder in oncological, haematological, and palliative-care settings: a meta-analysis of 94 interview-based studies. Lancet Oncology 2011; 18: 160-74. 
13. Shaheen Al Ahwal M, Al Zaben F, Khalifa DA, Sehlo MG, Ahmad RG, Koenig HG. Depression in patients with colorectal cancer in Saudi Arabia. Psychooncology 2015; 24 (9): 1043-50.

14. Fernández C, Padierna C, Villoria E, Amigo I, Fernández R, Peláez I. Repercusión de la ansiedad y depresión en el estado físico y funcionalidad de enfermos oncológicos durante el tratamiento con quimioterapia. Psicothema 2011; 23 (3): 371-81.

15. Krebber AM, Buffart LM, Kleijn G, Riepma IC, de Bree $\mathrm{R}$, Leemans CR, et al. Prevalence of depression in cancer patients: a meta-analysis of diagnostic interviews and self-report instruments. Psychooncology 2014; 23 (2):1 21-30.

16. Osborne RH, Elsworth GR, Sprangers MA, Oort FJ, Hopper JL. The value of the Hospital Anxiety and Depression Scale (HADS) for comparing women with early onset breast cancer with population-based reference women. Qual Life Res 2004; 13 (1): 191-06.

17. Rhondali W, Perceau E, Berthiller J, Saltel P, Trillet-Lenoir V, Tredan O, et al. Frequency of depression among oncology outpatients and association with other symptoms. Support Care Cancer 2012; 20 (11): 2795-802.

18. Torre-Luque A, Gambara H, López E, Cruzado JA. Psychological treatments to improve quality of life in cancer context: A meta-analysis. International Journal of Clinical and Health Psychology 2016; 16: 211-9.

19. Watts S, Prescott P, Manson J, McLeod N, Lewith G. Depression and anxiety in ovarian cancer: a systematic review and meta-analysis of prevalence rates. BMJ Open 2015; 5 (11): e007618.

20. Calderón J, Campla C, D’Aguzan N, Barraza S, Padilla O, Sánchez C, et al. Prevalence of emotional symptoms in Chilean oncology patients before the start of chemotherapy: potential of the distress thermometer as an ultra-brief screening instrument. Ecancermedicalscience 2014; 8: 437.

21. Chan C, Ahmad WA, Yusof M, Ho G, Krupat E. Effects of depression and anxiety on mortality in a mixed cancer group: a longitudinal approach using standardized diagnostic interviews. Psychooncology 2015; 24 (6): 718-25.

22. Moretti P, Dennis JL, Stella A, Alpini A, Cotichelli P, Ferolla $\mathrm{P}$, et al. Comorbility between anxiety and depression in patients with carcinoid tumors. Rivista di Psichiatria 2013; 48 (4): 301-6.

23. Zhang M, Peng L, Liu W, Wen Y, Wu X, Zheng M, et al. Physical and psychological predictors of quality of life in Chinese colorectal cancer patients during chemotherapy. Cancer Nurs 2015; 38 (4): 312-21.

24. Gil F, Costa G, Pérez FJ, Salamero M, Sánchez N, Sirgo
A. Adaptación psicológica y prevalencia de trastornos mentales en pacientes con cáncer. Med Clin (Barc) 2008; 130 (3): 90-2.

25. Rodgers J, Martin CR, Morse RC, Kendell K, Verrill M. An investigation into the psychometric properties of the Hospital Anxiety and Depression Scale in patients with breast cancer. Health and Quality of Life Outcomes 2005; 3: 41-4.

26. Schilli SM. Screening for distress in patients with cancer. Clinical Journal of Oncology Nursing 2014; 18 (6): 1036.

27. Zigmond AS, Snaith RP. The Hospital Anxiety and Depression scale. Acta Psychiatr Scand Suppl 1983; 67: 361-8.

28. Brennam C, Worral-Davies A, McMillan D, Gilbody S, House A. The Hospital Anxiety and Depression Scale: A diagnostic meta-analysis of case-finding ability. J Psychosom Res 2010; 69: 371-8.

29. Costa G, Pérez X, Salamero M, Gil FL. Discriminación del malestar emocional en pacientes oncológicos utilizando la Escala de Ansiedad y Depresión Hospitalaria (HADS). Ansiedad y Estrés 2009; 15 (2-3): 217-29.

30. Herrman C. International experiences with the Hospital Anxiety and Depression Scale: A review of validation data and clinical results. J Psychosom Res 1997; 42 (1): $17-41$.

31. López-Roig S, Terol MC, Pastor MA, Neipp MC, Massutí $\mathrm{B}$, Rodríguez-Marín J, et al. Ansiedad y depresión. Validación de la escala HAD en pacientes oncológicos. Journal Health Psychology 2000; 12 (2): 127-51.

32. Martínez P, Durá E, Andreu Y, Galdón MJ, Murgui S, Ibáñez E. Structural validity and distress screening potential of the Hospital Anxiety and Depression Scale in cancer. International Journal of Clinical and Health Psychology 2012; 12 (3): 435-47.

33. Cabrera V, Martín-Aragón M, Terol MC, Nuñez R, Pastor MA. La Escala de Ansiedad y Depresión Hospitalaria (HAD) en fibromialgia: análisis de sensibilidad y especificidad. Terapia Psicológica 2015; 33 (3): 181-93.

34. Herrero J, Blanch J, Peri JM, De Pablo L, Pintor A, Bulbena A. A validation study of the Hospital Anxiety and Depression Scale (HADS) in a Spanish population. Gen Hosp Psychiatry 2003; 25: 277-83.

35. Iani L, Lauriola M, Costantini M. A confirmatory bifactor analysis of the Hospital Anxiety and Depression Scale in an Italian community sample. Health and Quality of Life Outcomes 2014; 5 (12): 84.

36. Johnston M, Pollard B, Hennessey P. Construct validation of the hospital anxiety and depression scale with clinical populations. J Psychosom Res 2000; 48: 579-84.

37. Terol MC, Cabrera V, Martín M. Revisión de estudios de 
la Escala de Ansiedad y Depresión Hospitalaria (HAD) en muestras españolas. Anales de Psicología 2015; 31 (2): 494-503.

38. Norton S, Cosco T, Doyle F, Done J, Sacker A. The Hospital Anxiety and Depression Scale: a meta confirmatory factor analysis. J Psychosom Res 2013; 74 (1): 74-81.

39. Mitchell A, Meader N, Symonds P. Diagnostic validity of the Hospital anxiety and Depression Scale (HADS) in cancer and palliative settings: a meta-analysis. J Affect Disord 2010; 126 (3): 335-48.

40. Vodermaier A, Linden W, Siu C. Screening for emotional distress in cancer patients: a systematic review of assessment instruments. J Natl Cancer Inst Monogr 2009; 101: 1464-88.

41. Nikbakhsh N, Moudi S, Abbasian S, Khafri S. Prevalence of depression and anxiety among cancer patients. Caspian Journal Intern Medicine 2014; 5 (3): 167-70.

42. Özalp E, Sugür H, Cankurtaran E, Turhan L, Akbiyik D, Geyk P. Psychiatric morbidity and its screening in Turkish women with breast cancer: A comparison between the HADS and SCID tests. Psychooncology 2008; 17: 199-04.

43. Terol MC, López-Roig S, Rodríguez-Marín J, Martín-Aragón M, Pastor MA, Reig MT. Propiedades psicométricas de la Escala Hospitalaria de Ansiedad y Depresión (HADS) en población española. Ansiedad y Estrés 2007; 13 (2-3): 163-76.

44. Antúnez Z, Vinet EV. Escalas de depresión, ansiedad y estrés (DASS - 21): Validación de la Versión Abreviada en Estudiantes Universitarios Chilenos. Terapia Psicológica 2012; 30 (3): 49-55.

45. Lovibond S, Lovibond P. Manual for the depression anxiety stress scales. Sydney, Australia: Psychology Foundation of Australia; 1995.

46. Wolf EJ, Harrington KM, Clark SL, Miller MW. Sample size requirements for structural equation models: An evaluation of power, bias, and solution propriety. Educ Psychol Meas 2013; 76 (6): 913-34.

47. Boomsma A. Nonconvergence, improper solutions, and starting values in LISREL maximum likelihood estima- tion. Psychometrika 1985; 50: 229-42.

48. Bentler PM, Chou CH. Practical issues in structural modeling. Sociological Methods \& Research 1987; 16: 78-117.

49. Arbuckle JL. IBM SPSS Amos 20 User's Guide. Chicago: SPSS; 2011.

50. Bjelland I, Dahl AA, Haugh TT, Neckelman D. The validity of the Hospital Anxiety and Depression Scale. An updated literature reviews. J Psychosom Res 2002; 52 (2): 69-77.

51. Burgess C, Cornelius V, Love S, Graham J, Richards M, Ramírez A. Depression and anxiety in women with early breast cancer: five-year observational cohort study. BMJ 2005; 330 (7493): 702.

52. Fernández C, Amigo I, Villoria E, Padierna C, Fernández R, Peláez I. Influencia del estado emocional en la sintomatología referida por pacientes con cáncer de mama y cáncer de pulmón durante el tratamiento con quimioterapia. Medicina Paliativa 2013; 20 (4): 85-92.

53. Groenvold M, Petersen MA, Idler E, Bjorner JB, Fayers PM, Mouridsen HT. Psychological distress and fatigue predicted recurrence and survival in primary breast cancer patients. Breast Cancer Res Treat 2007; 105: 209-19.

54. Gil F, Costa G, Hilker I, Benito L. First anxiety, afterwards depression: Psychological distress in cancer patients at diagnosis and after medical treatment. Stress and Health 2012; 28 (5): 362-7.

55. Lloyd-Williams M, Dennis M, Taylor F. A prospective study to determine the association between physical symptoms and depression in patients with advanced cancer. Palliat Med 2004; 18: 558-63.

56. Villoria E, Fernández C, Amigo I, Padierna C, Gracia JM, Fernández R, et al. Comparación de la calidad de vida de dos grupos de pacientes oncológicos: pacientes libres de enfermedad a los cinco años y pacientes fallecidos. Medicina Paliativa 2012; 15: 338-45.

57. Vodermaier A, Millman RD. Accuracy of the Hospital Anxiety and Depression Scale as a screening tool in cancer patients: a systematic review and meta-analysis. Support Care Cancer 2011; 19: 1988-08. 